\title{
A comparative study of using a wooden storage box and storage platform for white yam tuber storage
}

\author{
Timothy AKPENPUUN ${ }^{1 *}$, Banjo AKINYEMI ${ }^{2}$, Tayo OYESOMI ${ }^{1}$
}

Received July 20, 2016; accepted February 24, 2018.

Delo je prispelo 20. julija 2016, sprejeto 24. februarja 2018.

\begin{abstract}
The study was undertaken to evaluate the performances of an experimental box and platform, as storage structures for white yam tubers (Dioscorea rotundata Poir.). The criteria used for evaluation were the degree of mass loss during storage, tuber sprouting and rotting during the 20 weeks storageperiod: March - June 2015. Measurements of temperatures and relative humidity of the storage environment were taken three times daily during the period. Mass loss in each tuber was measured weekly while sprouts were removed from tubers weekly. Results show that the average temperature and relative humidity in the experimental box were $29.7{ }^{\circ} \mathrm{C}$ and $78.6 \%$ respectively, while for the platform, they were $30.7^{\circ} \mathrm{C}$ and $76.5 \%$., respectively. Rotting was completely absent on tubers in both storage approaches. White yam tubers stored in the box exhibited a cumulative mass loss of $9 \%$, while on the platform, it was $15.0 \%$. The experimental box performed better in respect to mass loss and nutritional composition.
\end{abstract}

Key words: white yam; Dioscorea rotundata; storage techniques; , tuber mass loss; rotting; sprouting
IZVLEČEK

\section{PRIMERJAVA UPORABE LESENIH ZABOJEV IN PLATOJEV PRI HRAMBI GOMOLJEV BELEGA} JAMA

$\mathrm{V}$ raziskavi je je bila ovrednotena obstojnost gomoljev belega jama (Dioscorea rotundata Poir.) med shranjevanjem v lesenih zabojih in na platojih. Kriteriji za ovrednotenje ohranjenosti gomoljev so bili izguba mase, kalitev in gnitje gomoljev v obdobju 20 tednov, od marca do junija 2015. Meritve temperature in relativne zračne vlage $\mathrm{v}$ prostorih hrambe so potekale trikrat dnevno v obdobju trajanja poskusa. Meritve izgube mase vsakega gomolja so potekale tedensko, pravtako odstranjevanje kalečih poganjkov. Povprečna temperatura zraka in relativna vlažnost $\mathrm{v}$ poskusnih zabojih sta bili $29.7{ }^{\circ} \mathrm{C}$ in $78.6 \%$, v platojij $30.7^{\circ} \mathrm{C}$ in $76.5 \%$. Gnitja gomoljev ni bilo pri nobenem načinu hrambe. Gomolji belega jama, shranjeni v zabojih, so kumulativno izgubili $9 \%$ mase, tisti v platojih pa $15.0 \%$. Shramba v zabojih se je izkazala boljša glede izgube mase in hranilne vrednosti gomoljev.

Ključne besede: beli jam; Dioscorea rotundata; načini hrambe; izguba mase gomoljev; gnitje; kalitev

\section{INTRODUCTION}

The term yam is used for several economically important species of the genus of Dioscorea which belong to the monocotyledonous family Dioscoreaceae. Yams originated in the Far East and today are grown in most of the trpical regions for their edible tubers (enlarged, fleshy, usually underground storage stems). West and Central Africa account for about $94 \%$ of the world production, Nigeria being the major producer (Osunde, 2008).

Most edible yams species reach maturity in 8 to 11 months after planting. As a seasonal crop, harvested yam tubers are stored to meet the demand during the off season period. Adequate aeration, reduction of temperature, protection from direct sunlight and flood, and regular inspection are the basic requirements for successful and long term storage of yam tubers (Orhevba and Osunde, 2006; Sunmonu et al., 2017). Ventilation prevents moisture condensation on the tuber surface and is helpful in removing heat caused by respiration while low temperature is necessary to reduce losses from respiration, sprouting and rotting.

The storage structures may include trench or clamp silos, underground pits, barns of various designs, shelves in specially constructed or improvised sheds,

\footnotetext{
1 University of Ilorin, Department of Agricultural and Biosystems Engineering, Nigeria. *Corresponding author: akpenpuun.td@ unilorin.edu.ng

2 Landmark University, Omuaran, Department of Agricultural and Biosystems Engineering
} 
raised huts and assorted platforms. Storage techniques include cold storage, improved underground storage and improved yam barns. The popularity of these structures varies from one region to another, and the choice depends mainly on the volume to be stored and the cost (Adeniran et al., 2014).
Techniques and methods developed to reduce the physiological activities and also to protect tubers from post-harvest diseases can include treatments with plant extracts, palm wine and gamma irradiation, chemicals like gibberellic acid (GA), chloroisopropyl phenylcarbamate (CIPC), maleic hydrazide and other chemicals.

\section{MATERIALS AND METHODS}

\subsection{Plant material}

Mature white yam (Dioscorea rotundata Poir.) tubers from the second harvest period of 2014 growing season were obtained from the yam market in Ilorin. A detailed inspection was carried out in order exclude yam tubers that were mechanically damaged, and also to avoid yams gathered from early harvest period which are quite difficult to store due to high water content and are susceptible to rot. (Opara, 1999).

\subsection{Experimental site}

A well ventilated open area under a tree shade within the premises of the Department of Agricultural and Biosystems Engineering, University of Ilorin, was selected to simulate farm practice.

\subsection{Experimental setup}

The experiment was conducted from March to June 2015. The material used in the experiment included: wooden box, 20 fresh tubers of yam, a digital weighing balance, dry and wet bulb thermometer and a platform.

The tested storage techniques were an experimental box and a platform. The demensions of the experimental box (Figure 1) were $1.75 \times 1.50 \times 0.6 \mathrm{~m}$. All 20 yam tubers were weighed to determine the initial mass. Tubers were arranged without touching each other. Perforations were provided on the sides of the box for adequate ventilation purpose. For the construction of the storage platform, a total of four Y-shaped wooden columns measuring 1.2 $\mathrm{m}$ in length and $8 \mathrm{~cm}$ in diameter were erected at $0.9 \mathrm{~m}$ between the columns. The columns were erected to adepth of $30 \mathrm{~cm}$ into the ground. Four Bambusa vulgaris Schrad, ex J.C.Wendl. was used to construct the platform on which the yam tubers were stored. Rodent guards installed at the columns bases was made from aluminium sheets. The yam tubers were then heaped on the storage platform and covered with palm leaves.
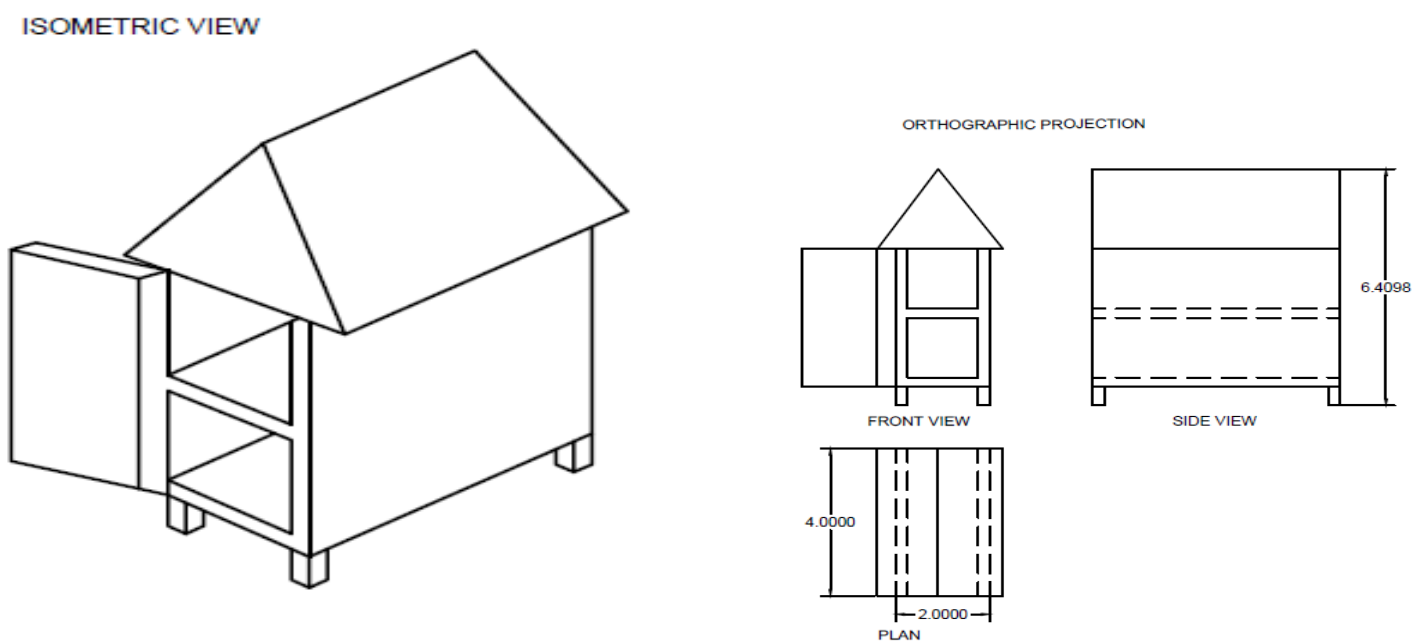

Figure 1: Isometric and orthographic projection of the experimental box for yam storage used in the study 


\subsection{Studied parameters}

\subsubsection{Temperature and relative humidity}

Temperature readings of the storage structure and environment were taken at 8.00 a.m, 12.00 p.m. and 5.00 p.m. on a daily basis during ten weeks using wet and dry bulb thermometers.

The amount of moisture contained in the atmosphere of the wooden box storage structure was determined with a hygrometer tables and psychometric chart and EL Wifi TH Lascar data logger to ensure the accuracy of the data obtained.

\subsubsection{Rotting and sprouting}

Evaluation of yam tubers in each storage structure included visual inspection and numerical recording. . The rotting index was determined according to Opara's (1999) formula shown in equation 1 :

$$
\text { Rotting Index }=\frac{\text { Number of deteriorated tubers }}{\text { Total number of tubers }} \times 100
$$

\subsubsection{Percentage mass loss determination}

The tubers were labeled to enable identification and weighed before the commencement of the experiment.
The mass of the tubers was recorded every week and the difference between subsequent masses represented the weekly loss. Mass was measured with the aid of a digital weighing balance having $0.5 \mathrm{~g}$ accuracy.

\subsubsection{Nutritional value}

The nutritional parameters such as moisture, ash and crude fiber contents were determined using Standard Chemical Methods described by Association of Official Analytical Chemistry (AOAC 1996). $2 \mathrm{~g}$ of each sample was oven dried at $105{ }^{\circ} \mathrm{C}$ for 24 hours in order to determine the moisture content, while the ash content was determined by incinerating $2 \mathrm{~g}$ of each sample in a muffle furnace at $500{ }^{\circ} \mathrm{C}$ for 2 hours. In the determination of the fat content of the samples, Soxhlet extraction technique was used. (Pearson et al., 1981). Kjedahl method was, however, used to determine the crude protein content of the samples as described by (AOAC, 1996). The percentage content of carbohydrate of the samples was estimated using equation 2 .

Carbohydrate content, $\%=(100-($ moisture + ash + fat + crude fibre + crude protein contents)

\section{RESULTS AND DISCUSSION}

\subsection{Temperature and relative humidity variation}

The experimental box and platform temperatures are presented in Figure 2. While the temperatures in the experimental box varied from 29.5 to $30.2{ }^{\circ} \mathrm{C}$ with an average value of $29.7{ }^{\circ} \mathrm{C}$, those within the platform varied from 30.2 to $31.04{ }^{\circ} \mathrm{C}$ with an average value of $30.7^{\circ} \mathrm{C}$. The temperatures within the experimental box were generally lower than those recorded in the platform for all periods throughout the experimentation period.. 


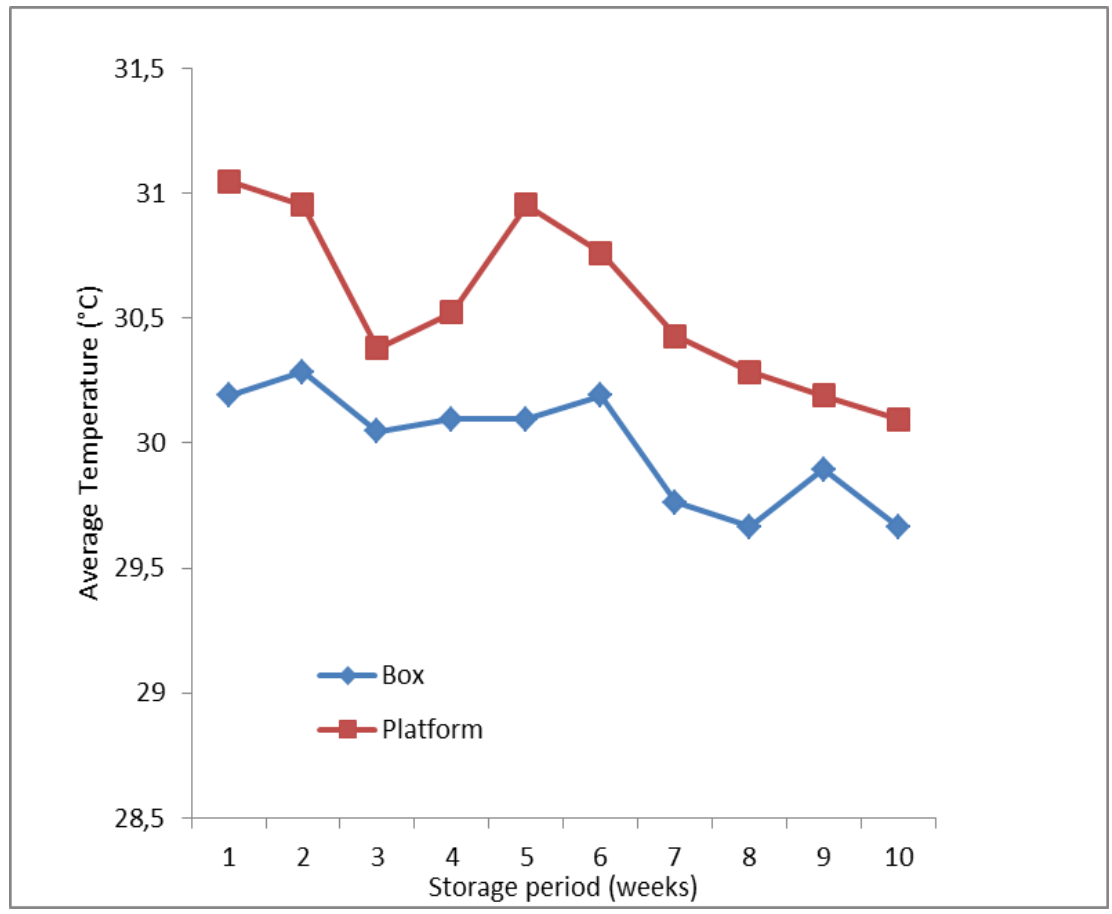

Figure 2: Temperature fluctuations with storage period

Temperature distribution trend is significant in the storage of yam tubers as it has a great influence on massloss High environmental temperature increases respiration rates, enhances significant sprouting activity during the late storage period and consequently causes a significant massloss of the tubers. The reason is that at high temperature, there is the tendency for increased metabolic activity and transpiration process, which are associated with the total energy content of the tuber, all resulting to massloss (Kay, 1973).

The relative humidity ranged from 77 to $80 \%$ with an average value of $78.6 \%$ for the experimental box while for the platform, the range was from 74 to $77 \%$ with an average of $76.5 \%$. (Figure 3 )

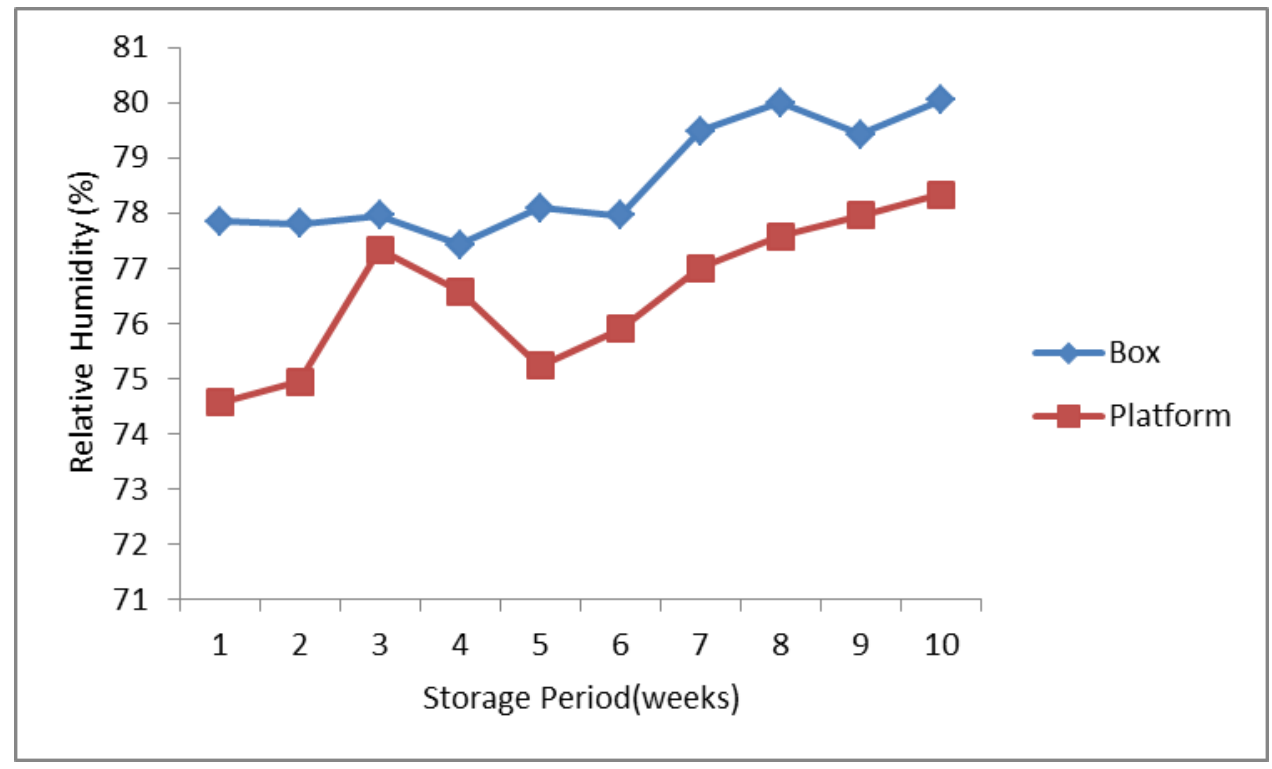

Figure 3: Relative humidity versus storage period 
The high humidity values recorded in the evaporative cooling box was attributed to the rainy season at that particular period of the year. The air in contact with it was often laden with moisture and high humidity condenses moisture from air.

\subsection{Mass loss}

Comparing the cumulative massloss of the tubers stored in the experimental box and those stored on the platform, it was observed that yam tubers in the experimental box sustained a massloss of 1.1 to $9.2 \%$ after 10 weeks of storage, while those in the platform exhibited a massloss ranging from 1.8 to $15.2 \%$ in the same storage period.

The weekly rate and cumulative masslosses observed in the stored yam tubers are presented in Figures 4 and 5 while the statistical analysis is presented in Tables 1 and 2 . The values of the weekly masslosses were higher on the platform than in the experimental box throughout the experimentation period. There was a significant difference $(p>0.05)$ between the rates of masslosses in the experimental box and the platform.

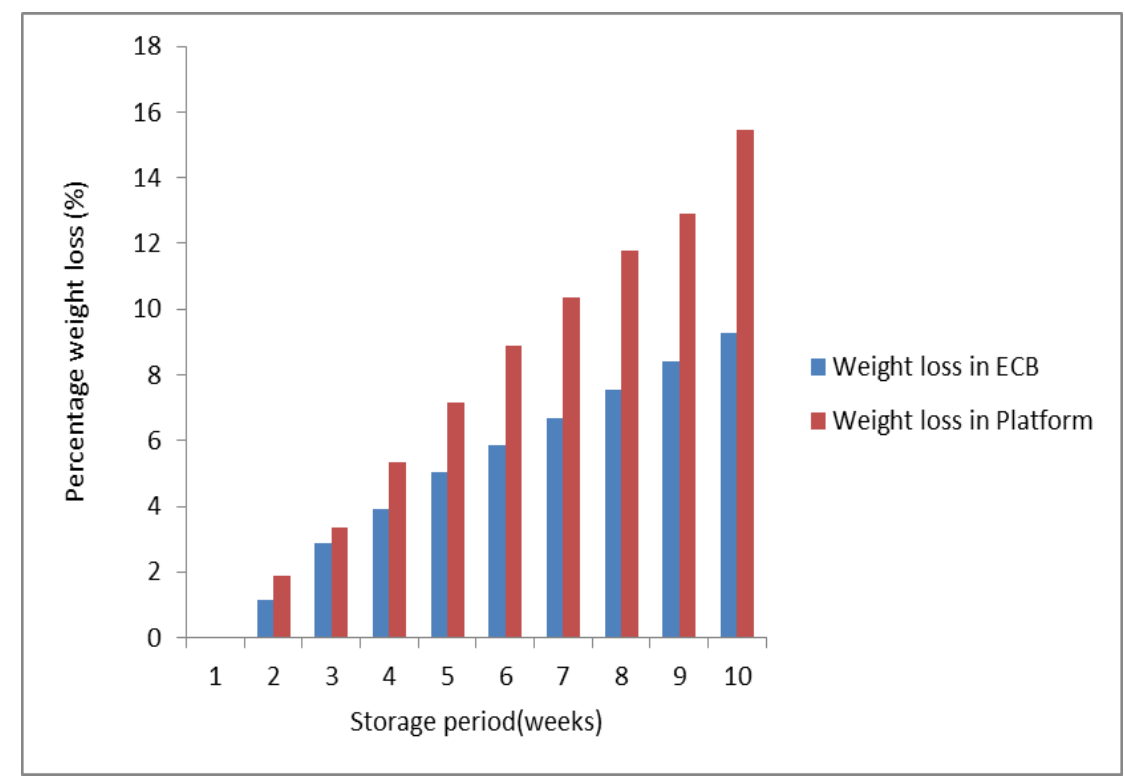

Figure 4: Weekly mass loss

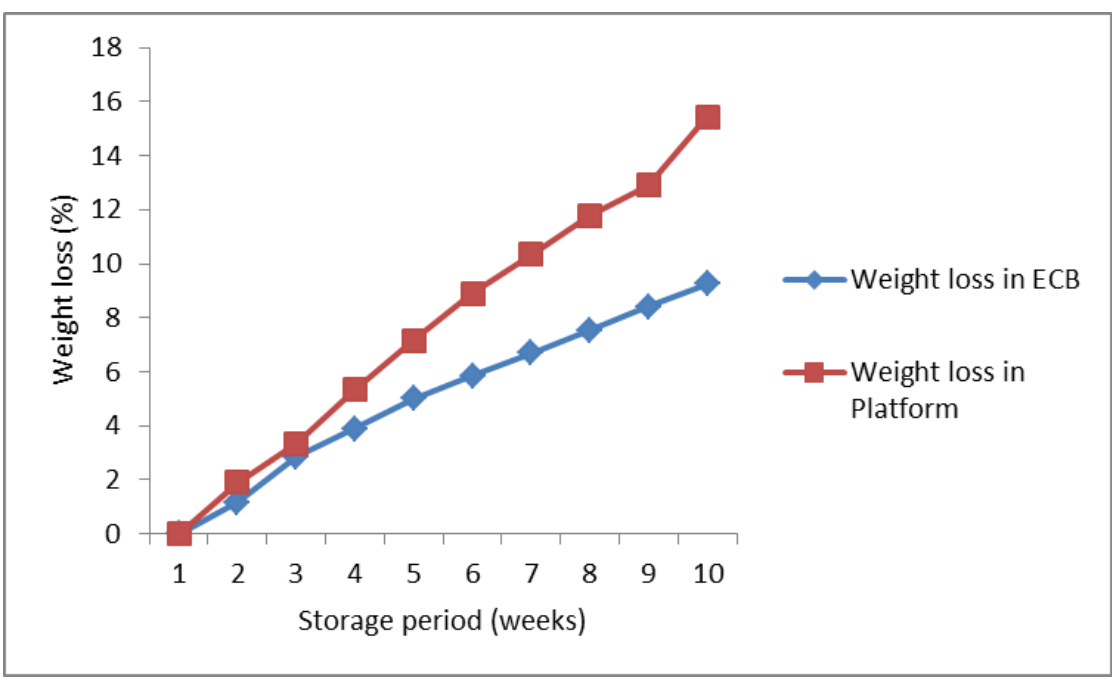

Figure 5: Cumulative mass loss 
Timothy AKPENPUUN et al.

Table 1: Analysis of variance of the mass loss recorded in the evaporative cooling box

\begin{tabular}{|c|c|c|c|c|c|}
\hline & \multicolumn{2}{|c|}{ Sum of Squares } & Mean Square & $\mathrm{F}$ & Sig. \\
\hline Treatment & .001 & 8 & .000 & 1.08 & 0.39 \\
\hline Error & .005 & 72 & .000 & & \\
\hline Total & .006 & 80 & & & \\
\hline
\end{tabular}

There is no significant different in the weight loss of the at $\alpha=0.05$

Table 2: Analysis of variance of the massloss recorded on the platform

\begin{tabular}{|c|c|c|c|c|c|}
\hline & \multicolumn{2}{|c|}{ Sum of Squares } & Mean Square & $\mathrm{F}$ & Sig. \\
\hline Treatments & .001 & 8 & .000 & 2.46 & .02 \\
\hline Errors & .002 & 72 & .000 & & \\
\hline Total & .003 & 80 & & & \\
\hline
\end{tabular}

There is significant different in the weight loss of the second structure $\alpha=0.05$

\subsection{Proximate Analysis}

An account on the effect of the storage conditions (evaporative cooling box and platform) on the nutritional composition of white yam selected for the study is given in Table 3. The analysis was done just before and after the storage experiment. The nutritional composition analyzed comprised the ash, carbohydrates, fats and oil, fiber, moisture and protein contents.

Table 3: Proximate analysis of yam tubers before and after storage

\begin{tabular}{llll}
\hline Parameters & Before storage & Experimental box & Platform \\
\hline Moisture Content \% & 43.26 & 42.62 & 34.38 \\
Ash Content \% & 2.57 & 2.08 & 1.64 \\
Fat and Oil \% & 1.75 & 1.53 & 1.41 \\
Crude Fiber \% & 0.95 & 2.79 & 2.23 \\
Carbohydrate Content \% & 51.47 & 47.01 & 32.72 \\
\hline
\end{tabular}

\subsection{Physical observation}

Rotting of white yam tubers was one of the physiological parameters considered in this study. There was however no incidence of rotting among the white yam tubers stored on the platform and experimental box throughout the period of the experiment. Sprouting is promoted by humid environment and high temperatures. Higher relative humidity and temperatures within the white yam tubers stored in the experimental box were the major factors responsible for the higher level of sprouting in the experimental box than the platform. 


\section{CONCLUSIONS}

Yam tubers were stored in an experimental storage box and storage platform over a period of 20 weeks. While the experimental box maintained an environment of $29.5^{\circ} \mathrm{C}$ and $78.6 \%$ relative humidity, the platform environment was $30.7^{\circ} \mathrm{C}$ and $76.5 \%$ relative humidity. The tubers stored in the experimental box were observed to have sprouted more than those on the platform but the overall massloss of the yam tubers was more on the platform $(15.2 \%)$ than in the experimental box $(9.2 \%)$. There was no rotting observed among the tubers stored. The experimental box is able to reduce the massloss which could be an advantage for farmers as yams are priced on massbasis and it may therefore be preferred.

Further work which should involve longer storage periods and determination of the sensory qualities of the stored white yam tuber is recommended.

\section{REFERENCES}

Adejumo O. I. (1998). Yam storage structures in western Nigeria. Proceedings of the Nigeria Society of Agricultural Engineers (NSAE) conference, Bauchi, Nigeria. pp. 143- 151.

Adeniran, K. A., Mijinyawa, Y., Akpenpuun, T. D. and Oseni T. D. (2014). Engineering Properties of Termite Mound Bricks as a Construction Material for Agricultural Buildings. Journal of Agricultural Engineering and Technology (JAET), 22 (4), pp. $143-150$.

Ajadi, B.S., Adeniyi A., Afolabi M. T. (2011). Impact of climate on urban agriculture: Case Study of Ilorin City, Nigeria. Global Journal of Human Social Science, 11 (1), pp. 12. 25.

(AOAC), 1996. Official methods of analysis of the association of the official analytical chemists. 19th Edn.,Washington DC.

Food and Agriculture Organization of the United Nations (FAO) (1998). Storage and processing of Roots and Tubers in the Tropics. International Institute of Tropical Agriculture (IITA) 2007. Yam research for development. IITA Publication 1, pp. 1-10.

Hahn S.K., D.S.O. Osiru, M.O. Akoroda and J.A. Otoo (1987). Yam production and its future prospect. Outlook on Agriculture, 16(3), 105-109. https://doi.org/10.1177/003072708701600302

Kay, D.E. (1973). Crop and product digest. Root crops. 2nd Edition, London.

Knoth J. (1993). Traditional Storage of Yams and Cassava and Its Improvement. http://goo.gl/1ItQpD

Opara L. U. (1999). Yam Storage In: Bakker-Arekema et al. (eds). CIGR Handbook of Agricultural
Engineering. Vol. IV. Agro Processing 182 - 214. The American Society of Agricultural Engineers.

Orhevba B. A, Osunde Z. D. (2006). Effects of storage condition and cipc treatments on sprouting and weight loss of stored yam tubers. Proceedings of the 28th Annual Conference of the Nigerian Institution of Agricultural Engineers. 28, pp. 352360.

Orkwor, G.C, R. Asiedu and I.J Ekanayake eds. (1998). Food Yams: Advances in: Research, IITA, Ibadan and NRCRI, Umudike, Nigeria. 249p.

Osagie A.U. (1992). The yam tuber in storage. PostHarvest Research Unit, University of Benin, Nigeria pp. 107-173.

Osunde, Z.D. and Orhevha, B. A. (2009). Effect of storage condition and storage period on nutritional qualities of stored yam (Diacorea spp) Tubers. AJF, 9 (2) $678-690$.

Osunde Z. D. and M. G. Yisa (2000). Effect of storage structures and storage period on weight loss and sprout growth on stored yams. Proceedings of the First International Conference and Millenium General Meeting of the Nigerian Institution of Agricultural Engineers held at University of Ibadan, Ibadan.

Pearson, D., H. Egan, R.S. Kirk and R. Sawyer (1981). Pearson's chemical analysis of food. Edinburgh: Churchill Livingston.

Sunmonu, M. O., Odewoleb, M. M., Obajemihic, O. I., Akpenpuund, T. D. and M. Jimoh (2017). Development of Battery Operated Evaporative Cooling System for Storing Perishables. The Journal of the Association of Professional Engineers of Trinidad and Tobago, 45 (2), 21-25. 